\title{
LIBERDADE ACADÊMICA EM TEMPOS DIFÍCEIS: DIÁLOGOS BRASIL E ESTADOS UNIDOS
}

\author{
ACADEMIC FREEDOM IN HARD TIMES: \\ DIALOGUES BRASIL AND UNITED STATES
}

\author{
Marcelo Andrade Cattoni de Oliveira \\ Mestre e Doutor em Direito pela Faculdade de Direito da Universidade Federal de Minas Gerais. \\ Pós-Doutorado pela Università degli studi di Roma III. \\ Professor Associado VI de Direito Constitucional da FD/UFMG.
} mcattoni@gmail.com

\begin{abstract}
MARIA FERNANDA SALCEDo REPOLÊS
Mestre em Filosofia pela Faculdade de Filosofia da Universidade Federal de Minas Gerais. Doutora em Direito pela Faculdade de Direito da Universidade Federal de Minas Gerais. Pós-Doutorado pela Universidade Federal do Rio de Janeiro. Professora Residente do Instituto de Estudos Avançados Transdisciplinares da UFMG Professora Adjunta IV da FD/UFMG. mariaf.salcedo@gmail.com

Francisco de CASTILho Prates Mestre e Doutor em Direito pela Faculdade de Direito da Universidade de Minas Gerais. Estagiário de Pós-Doutorado (Bolsista da CAPES)
\end{abstract} castilho_2011@yahoo.com

\section{RESUMO}

0 artigo busca trabalhar a liberdade acadêmica, seu papel e seus possíveis limites e fronteiras, a partir do paradigma do Estado Democrático de Direito, como configurado em nosso texto constitucional de outubro de 1988. O enfoque se dá na relação entre o papel crítico e investigativo esperado das Universidades e de seus membros, diante das chamadas propostas legislativas do movimento Escola Sem Partido. Isto é, perguntamos se estas propostas não ofenderiam a liberdade constitucional de professores, alunos, técnicos e pesquisadores, além das próprias instituições de ensino superior, quanto a assuntos que gravitam em torno de suas funções e responsabilidades. Para este fim, sem olvidarmos de nosso próprio contexto constitucional, decidimos dialogar com o direito comparado, principalmente com o cenário estadunidense e certas decisões da Suprema Corte dos Estados Unidos que lidam com a mesma temática aqui abordada. Conclui-se que a liberdade acadêmica tem um papel essencial, constitucionalmente reconhecido, no Estado Democrático de Direito.

Palavras-chave: Liberdade Acadêmica; Limites; Estado Democrático de Direito.

\begin{abstract}
This paper intends to discuss the academic freedom, its role and its possible limits and borders, from the paradigm of the Democratic Constitutional State, as configured in our constitutional text of October 1988. The discussion focuses on the relationship between the critical and investigative role expected of the Universities and of its members in relation to the socalled legislative proposals of the Escola Sem Partido movement. Hence, it explores if these proposals do not offend the constitutional freedom of professors, students, technicians and researchers, in addition to the higher education institutions themselves, when subjects that gravitate around their roles and responsibilities are taken into account. For this purpose, keeping in mind our own constitutional context, we decided to use Comparative Law, focusing on decisions of the Supreme Court of the United States that deal with the same issue addressed here. The analysis indicates that academic freedom has an essential and constitutionally recognized role in the Constitutional Democracy.
\end{abstract}

Keywords: Academic Freedom; Limits; Constitutional Democracy. 


\section{SUMÁRIO}

INTRODUÇAO; 1 PENSANDO A LIBERDADE ACADÊMICA A PARTIR DO BRASIL; 2 ACADEMIC FREEDOM: APONTAMENTOS ESTADUNIDENSES; CONCLUSÃO; REFERÊNCIAS.

\section{INTRODUÇÃO}

Uma professora de sociologia da rede estadual de ensino paranaense tornou-se personagem principal de uma polêmica, em razão de um vídeo por ela postado nas redes sociais no qual os conceitos da teoria do pensador Karl Marx são repassados aos alunos utilizando como ferramenta de ensino a melodia de uma famosa música funk.

Acusada de apologia ao marxismo, a professora respondeu que, em realidade, visava promover e aprofundar, entre seus alunos, discussões a respeito de vários pensadores da sociologia, não apenas Marx. Além disso, salientou que estes mesmos pensadores estavam presentes nas “diretrizes curriculares”.

Em outra situação, agora no Distrito Federal, uma deputada distrital solicitou, através de ofício dirigido a uma escola de Ceilândia, "providências legais" em relação a um professor pelo motivo deste ter abordado, com seus alunos, questões envolvendo homofobia, orientação sexual, entre outros temas relacionados a gênero e sexualidade.

Estes casos, entre outros que têm sido noticiados, refletem certas propostas legislativas do movimento Escola Sem Partido ${ }^{1}$, as quais, em breve síntese, visam combater aquilo que entendem ser “doutrinação para um projeto único de poder”, e não ensino e aprendizagem. Tais iniciativas buscam normatizar, restringindo e responsabilizando, um suposto "aparelhamento ideológico do sistema educacional”, seja por parte dos quadros docentes, presencialmente, seja através da presença subliminar nos livros didáticos adotados.

Em outros termos, pretende-se combater determinadas visões de mundo tidas como contrárias a dados valores considerados como tradicionais da família e da sociedade, propondo, até mesmo, a tipificação penal de uma espécie de "assédio ideológico", com a previsão de

${ }^{1}$ Cf.: Projeto de Lei do Senado (PLS) N ${ }^{\circ}$ 193/2016. Inclui entre as diretrizes e bases da educação nacional, de que trata a Lei n 9.394, de 20 de dezembro de 1996, o “Programa Escola sem Partido". 
sanções aos professores e outros agentes pedagógicos que porventura sejam condenados, com base em tais condutas. ${ }^{2}$

Estes casos e propostas colocam em debate o âmbito normativo do que seja liberdade de ensino e aprendizagem em um Estado Democrático de Direito que se assume aberto e plural. Ou seja, quais as fronteiras aos processos de conhecimento em democracias constitucionais? Criminalizar o ambiente de ensino é uma saída que se revela validável discursivamente? Impedir, aprioristicamente, que certos temas ou pensadores sejam debatidos com os alunos não configuraria uma intervenção ilegítima, por parte do Estado, nas interações educacionais? Não seria um ressurgimento de um index inquisitório? Ou, talvez, uma tentativa brasileira de chegarmos a impor, aos nossos docentes universitários, algo como os infelizes loyalty oath ${ }^{3}$, juramentos de lealdade, dos anos de chumbo do Macarthismo ${ }^{4}$ estadunidense?

São indagações como estas que nos movem a procurar configurar uma concepção, que consideramos constitucionalmente adequada, do direito fundamental de ensinar e aprender. Por constitucionalmente adequada entendemos aquelas posições que não negam o pluralismo constitutivo de nossas sociedades, nem restringem o direito a divergir, não se fundamentando em estereótipos excludentes.

Em suma, nossas análises assumem, como pressuposto, a ideia do Estado Democrático de Direito com um projeto histórico, sempre inconcluso e, por isto, também sempre arriscado, de aprendizagem e luta por reconhecimento e redefinição das liberdades. Em outros termos, partimos do conceito de patriotismo constitucional, em que o povo, não mais unidade substancial, constrói-se como "instância política plural”, implicando a defesa da

[...] construção de uma cultura política pluralista com base na Constituição democrática, de uma República de cidadãos livres e iguais, como expressão de uma forma de integração social, que se dá, portanto, através da construção dessa identidade política pluralista e aberta, que pode ser sustentada por diversas formas de vida e identidades socioculturais, que convivem entre si, desde que assumam uma postura não fundamentalista de respeito recíproco, umas em relação às outras. (CATTONI DE OLIVEIRA, 2013: 140)

\footnotetext{
${ }^{2}$ Cf.: Projeto de Lei $1411 / 2015$, o qual pretende, alterando o Código Penal, "tipificar o crime de assédio ideológico", além de outras alterações normativas na mesma linha.

${ }^{3}$ Cf.: (SCHRECKER, 1999) e (MORRIS, 1963).

4 Termo dado ao período, em plena Guerra Fria, em que as liberdades nos Estados Unidos foram mais ameaçadas, levando este nome em razão do Senador McCarthy, que conduziu uma comissão que investigava a suposta influência comunista no contexto daquele país, questionando o patriotismo dos cidadãos que aparentavam defender ideias tidas como subversivas, levando inúmeros professores a serem delatados e sabatinados, até que conseguissem demonstrar sua lealdade. Cf.: (SCHRECKER, 1986) e (APTHEKER, 1962).
} 
Sempre tendo como pano fundo esta visão de democracia constitucional, aproveitamos este momento para destacarmos que, em razão da enorme complexidade do tema proposto, recortes são necessários, não só por causa de todos os limites presentes em qualquer ato de conhecer, mas também em virtude do espaço que aqui dispomos. Sendo assim, decidimos não adentrar nos aspectos que versam sobre os denominados ensinos fundamental e médio, não obstante sermos sabedores dos profundos impactos que algumas das propostas legislativas que têm sido apresentadas podem ocasionar nestas dimensões da formação educacional.

Dito isto, a nossa ênfase será no campo da liberdade acadêmica em instituições públicas, buscando aferir as consequências que estas concepções de escolas sem partido podem desvelar no ensino, pesquisa e extensão universitária.

Em breves palavras, qual o sentido e o alcance da liberdade acadêmica? Como esta pode ser impactada por iniciativas legislativas que podem acabar por reduzir, de modo drástico, o campo de investigação, já que demonstram possuir um potencial intimidatório? Isto é, qual o âmbito protetivo desta liberdade fundamental que, se atingido, negaria os próprios pressupostos de um Estado Democrático de Direito, como o aqui assumido?

Entre tantos caminhos que poderíamos percorrer na tarefa de problematizar a liberdade acadêmica, procuramos estabelecer um diálogo entre argumentos esposados pelo Supremo Tribunal Federal em um específico caso e decisões da Supreme Court estadunidense, além de apontarmos alguns posicionamentos doutrinários presentes no contexto norte-americano, buscando construir uma noção de liberdade acadêmica defensável em arenas públicas ampliadas.

\section{PENSANDO A LIBERDADE ACADÊMICA A PARTIR DO BRASIL}

Partindo da Constituição Federal de 1988, podemos perceber que o direito fundamental à educação está relacionado com um processo histórico de luta por reconhecimento das liberdades dos cidadãos, de integração social que assume e trabalha a diversidade social.

Em termos históricos, após um período de extrema censura da livre circulação das ideias, foi instaurada em 01 de fevereiro de 1987 a Assembleia Nacional Constituinte, durante a qual eram visíveis posições que se guiavam por maior autonomia e liberdade na construção dos saberes, o que não significa que fossem de amplo consenso, mas ao contrário, sempre foram 
motivo de tensos diálogos entre as correntes políticas que compunham aquela referida Constituinte.

A título ilustrativo, tomemos o Anteprojeto Afonso Arinos, neste, podemos ler uma importante passagem para a configuração de nosso pano de fundo de debates, isto é, que o processo educacional, sempre tendo como parâmetro a democracia e os direitos humanos, é

[...] inseparável dos princípios da igualdade entre o homem e a mulher, do repúdio a todas as formas de racismo e de discriminação, do respeito à natureza e aos valores do trabalho, dos imperativos do desenvolvimento nacional, da convivência com todos os povos, da afirmação das características mestiças e do pluralismo cultural do povo brasileiro. (Anteprojeto Constitucional, Setembro, 1986: 52)

Ainda que sem a mesma redação, podemos perceber que estas mesmas assertivas podem ser comprovadas, por exemplo, na Seção I, do Capítulo III de nosso vigente texto constitucional, configurando os parâmetros gerais de nosso sistema educacional. Neste capítulo, entre outras normas, podemos visualizar a ênfase que o constituinte deu a "liberdade de aprender, ensinar, pesquisar e divulgar o pensamento, a arte e o saber", ao "pluralismo de ideias e de concepções pedagógicas”. Além disso, a autonomia universitária é também destacada, não só em seu campo próprio, ou seja, "didático-científico", mas também na sua autogestão "administrativa e financeira".

Já em termos infraconstitucionais, temos a chamada Lei de Diretrizes e Bases das Educação Nacional (Lei Federal n 9.394/1996), em que os princípios constitucionais de liberdade, igualdade, autonomia e pluralismo, tanto de ideias quanto de concepções pedagógicas na área educacional, no processo de ensino/aprendizagem, também se fizeram sentir, irradiando toda a sua força conformadora.

Naquilo que tange mais especificamente ao modo como está configurada a liberdade acadêmica, realçamos que a citada legislação dispõe que a educação de nível superior visa a construção de um "pensamento reflexivo", problematizador, voltado para o aprofundamento e o estímulo das investigações científicas, sendo necessário, para isto, a mais ampla possibilidade de divulgação dos resultados dos trabalhos ocorridos nas Universidades. Alia-se a isto, além da ênfase na participação social nas conquistas advindas deste processo de educação superior, a defesa da mais ampla autonomia destas instituições de ensino.

Nesta linha, vemos, com Samantha Ribeiro Meyer-Pflug, que esta conformação da liberdade acadêmica garante aos "[...] professores ministrarem suas aulas de acordo com suas 
convicções e ideias, sem sofrerem restrições por parte do Estado, sem seguir um modelo previamente estabelecido" (MEYER-PFLUG, 2009: 48), além de lembrar que esta mesma liberdade fundamental "proíbe que o Estado venha se opor à adoção de determinadas teorias científicas, como acontecia no passado [...]". (MEYER-PFLUG, 2009: 48)

Por sua vez, José Afonso da Silva, empregando o conceito de liberdade de transmissão $e$ recepção do conhecimento (SILVA, 1997: 248), enfatiza tratar-se “do reconhecimento de liberdade de uma classe de especialistas na comunicação do conhecimento, que são os professores". Em sua visão, a noção tradicional de "liberdade de cátedra era mais restritiva, por estar vinculada à ideia de catedrático, que recebia conotação de titularidade de certos cargos do magistério". (SILVA, 1997: 248)

0 mesmo professor ressalta que esta liberdade, constitucionalmente garantida, implica o 'outro', ou seja, “a liberdade de aprender”, “de pesquisar” (SILVA, 1997: 248), construída, dialogicamente, com aqueles com quem é compartilhada, os estudantes, sujeitos ativos do processo de conhecer, não objetos da aprendizagem. ${ }^{6}$

Desta maneira, a liberdade de acadêmica, a qual, diga-se, é traduzida constitucionalmente no momento em que lemos sobre as liberdades de aprender, de ensinar, de pesquisar e de divulgar (art. 206, II), desvela o aspecto dialógico destas liberdades fundamentais, as quais não são excludentes, mas ao inverso, como ainda buscaremos demonstrar, pressupõem-se em constitutiva tensão.

Partindo deste cenário, será que já podemos construir algumas considerações no que se refere ao papel esperado tanto dos professores universitários quanto das instituições públicas de ensino superior, em um contexto que se afirma democrático?

Entendemos que sim. Uma seria aquela decorrente de todo o contexto normativo antes elencado, qual seja, para que pesquisas sejam realizadas a contento, para que o conhecimento não se ossifique em dogmas inquestionáveis, para que a crítica possa realmente dinamizar os

\footnotetext{
${ }^{5}$ Aproveitamos esta passagem para anotar que empregamos, preferencialmente, o termo liberdade acadêmica em virtude deste, abarcar as diversas facetas desta liberdade fundamental, ou seja, ensinar, aprender, pesquisar e publicar, referindo-se, tanto a questões docentes, discentes e institucionais, suas respectivas autonomias, limites e tensões. Já liberdade de cátedra, quando citada, diz respeito ao campo de atuação dos professores, sendo mais restrita, diríamos nós, unilateral.

${ }^{6}$ Ainda que não seja nosso objeto, não nos furtamos de pontuar que a relação de ensino e aprendizagem, ao menos em democracias constitucionais, não pode ser configurada monologicamente, pois, como anotava Paulo Freire (1982), não há educação democrática sem espaço para participação, para diálogo e decisões compartilhadas sobre os problemas e visões de mundo. Assim, os docentes não devem recusar os debates, como se o fato de serem professores os qualificasse com autoridade inquestionável, a qual, por si mesma, edificaria uma verdade derradeira.
} 
debates, faz-se mister uma ampla liberdade acadêmica, tomada esta, em termos relacionais, abrangendo a instituição, os docentes e o corpo discente.

Em outras palavras, esta liberdade implica que ingerências externas aos ambientes acadêmicos devem ser tidas como excepcionais, devendo operar como mecanismos que possam fomentar ainda mais os espaços livres do conhecer. Ou seja, estas intervenções, advindas do aparato estatal ou de algum outro ator externo às universidades públicas devem, elas próprias, estar vinculadas àqueles compromissos constitucionais que conformam o ensino superior, não devendo, por exemplo, refletir desejos de maiorias morais que se opõem, de modo absoluto, a que certos temas sejam problematizados por aqueles que integram estas instituições de ensino.

Além disso, há dois outros pontos que merecem ser destacados: o primeiro é que a liberdade acadêmica não é apenas contra injunções externas, possuindo também uma face interna, ou seja, na relação intramuros, entre os docentes e pesquisadores e as instituições que estão vinculadas, já que possíveis atos de censura, mesmo que dissimulados, podem aparecer tanto por pressões externas, quanto nas interações internas.

O segundo é aquele que emerge da própria sistemática constitucional, isto é, que nenhuma liberdade, incluindo a acadêmica, em qualquer de suas vertentes, é ilimitada, mas estes limites, porventura impostos, não podem operar sem uma base discursiva de fundamentação pública.

Como efeito, estes limites devem ser construídos como condição de possibilidade da própria liberdade acadêmica, potencializadores e difusores do conhecimento, fazendo com que esta liberdade opere como uma prerrogativa, não um privilégio imunizador, como se docentes e universidades tudo pudessem fazer, sem qualquer possibilidade de responderem por suas falas. Isto é, não há que se pensar em liberdade acadêmica para fomentar discursos de intolerância, de ódio ${ }^{7}$, já que estes discursos contrariam os próprios pressupostos dialógicos que perpassam o nosso texto constitucional.

Posto de outro modo, não há como desvincularmos esta liberdade, sua força motriz emancipadora, dos compromissos do Estado Democrático de Direito, tomado este como espaço da possibilidade, sempre presente, de desconstrução do naturalizado, da abertura ao outro, em

\footnotetext{
${ }^{7}$ Podemos conceituar os discursos de ódio como falas excludentes, voltadas a ofender grupos sociais em razão de sua origem étnica, nacionalidade, religião, orientação sexual ou qualquer outra singularidade vista como inassimilável pela maioria. Isto é, práticas argumentativas que buscam, obsessivamente, aniquilar o "estranho" e a sua "insuportável e indesejável diferença", como se este outro portasse alguma "doença contagiosa" da qual a sociedade precisasse ser "curada". Sobre tal tema, conferir, entre outros: (TSESIS, 2009) e (PRATES, 2015).
} 


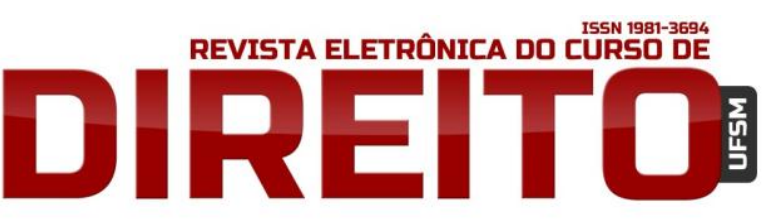

LIBERDADE ACADÊMICA EM TEMPOS DIFÍCEIS: DIÁLOGOS BRASIL E ESTADOS UNIDOS

MARCELo ANDRADE CATTONI DE OLIVEIRA MARIA FERNANDA SALCEDo REPOLÊS FRANCISCO de CASTILHO PRATES

que o democrático é algo que nunca está pronto e acabado. Ou seja, pensar esta liberdade é, ao mesmo tempo, refletir sobre o sentido da democracia, haja vista que são "intrínsecas" as relações entre o “Estado Democrático e a Educação” (TEIXEIRA, 1968: 80).

Indo às veredas do direito comparado, procurando iluminar ainda mais este ponto de nossas assertivas, remetemo-nos ao caso Regina v. Keegstra (1990), ainda que este não abordasse diretamente a questão da liberdade acadêmica, estando mais próximo da dimensão geral da liberdade de expressão.

0 referido caso envolvia um professor de ensino médio, James Keegstra, que fazia apologia de ideias antissemitas, o que levou o mesmo a ser processado e condenado, nas instâncias inferiores, por incitar o ódio contra um grupo social identificável.

Observemos que Keegstra não só promovia suas opiniões durante as suas aulas, como as incentivava, já que os alunos que "reproduzissem" as suas concepções recebiam notas mais altas. Um destes "ensinamentos" colocava que o Holocausto teria sido inventado pelos judeus como forma de angariar simpatia internacional aos seus interesses.

Ora, por maioria, a Suprema Corte canadense decidiu que era constitucional o limite imposto ao referido professor, já que tal limite mostrava-se razoável e necessário, haja vista que restringir discursos de ódio, naquela situação, coadunava-se com a busca de se construir uma sociedade mais pluralista e equilibrada.

Denota-se, com base no decidido em Keegstra, que defender uma ampla liberdade de ensino, acadêmica, não pode significar, como já temos buscado demonstrar, a edificação de territórios imunes, haja vista que a mesma não deve ser lida isoladamente, como se estive em um plano superior aos próprios ordenamentos constitucionais. Percebe-se, também, que as responsabilizações, os limites, devem ser não só legítimos em termos discursivos, como também razoáveis e necessários, funcionando estes, como já expomos, como condição de possibilidade de uma sociedade democrática.

Logo, assume-se que certas falas, por serem radicalmente excludentes, não estão cobertas pelo aparato protetivo da liberdade acadêmica, não podendo ser justificadas em termos das funções, constitucionalmente esperadas, por parte de pesquisadores e demais integrantes dos quadros universitários. Ou seja, "the justification of academic freedom must therefore be sought in the peculiar character and function of the university scholar". (VAN ALSTYNE, 1972: 142)

Dito de outro modo, a 
[...] 'academic freedom', in the context 'the academic freedom of a faculty member of an institution of higher learning', refers to a set of vocational liberties: to teach, to investigate, to do research, and to publish on any subject as a matter of professional interest, without vocational jeopardy or threat of other sanction, save only upon adequate demonstration of an inexcusable breach of professional ethics in the exercise of any of them. (VAN ALSTYNE, 1972: 146, negritos nossos)

Em suma, não há, em um Estado Democrático de Direito, como legitimar, por exemplo, pesquisas que buscam, sob o manto de uma pseudocientificidade, comprovar, indo contra princípios fundacionais deste paradigma de Estado, que alguns grupos sociais são inferiores a outros em razão de sua origem, orientação sexual ou cor. Do contrário, teríamos que admitir a existência de uma liberdade constitucional para ofender, humilhar e excluir, o que soa como uma contradição performativa em termos de democracia constitucional.

Verifica-se, assim, que liberdade acadêmica não é instrumento protetivo para insultos, o que explica, como ressalta Dworkin, que “[...] quando uma universidade proíbe ou desestimula o insulto, ela reconhece os limites da doutrina, mas não a compromete". (DWORKIN, 2006: 407) Todavia, como o mesmo professor estadunidense adverte, “[...] temos de tomar muitíssimo cuidado para distinguirmos os casos em que o insulto é intencional daqueles em que não é, embora os efeitos da palavra ou do gesto possam ser os mesmos". (DWORKIN, 2006: 407)

Mas identificar tais fronteiras não é uma tarefa fácil, ainda mais em um contexto altamente complexo e marcado por autoritarismos, historicamente verificáveis, como o brasileiro. Assim, embora dado tema possa ser considerado pela maioria da opinião pública como controverso, polêmico, ou até mesmo, por algum fator moralista, desagradável, isso não pode significar que este não possa ser debatido nas salas de aula das graduações e pós-graduações, já que vimos que estas são, constitucionalmente, espaços das discussões abertas, das verdades construídas dialogicamente, sempre podendo ser reinquiridas e revertidas, não locus de contrição diante de dogmas de fé.

Visualiza-se, deste modo, a defesa daquilo que Dworkin, denominou de "cultura de independência", aquela que se opõe ao conformismo e ao endurecimento das ideias, que não parte de "tradições monolíticas", nem entende que o ato de discordar é sinônimo de traição, ou seja, liberdade acadêmica como o oposto de algo similar a uma "epistemologia totalitária". (DWORKIN, 2006: 399-403). 
Esta cultura da independência, exigência de democracias constitucionais, demonstra que a liberdade acadêmica, a liberdade de pesquisar e ensinar, deve ser construída não como algo elitista, que só interessa aos professores ou às universidades, mas, sim, que diz respeito a toda sociedade (DWORKIN, 2006: 399).

Seria uma liberdade para compartilhar conhecimentos, não para restringi-los a poucos eleitos, potencializando questionamentos, em que assuntos como aborto, gênero, evolucionismo e eutanásia, entre outros, não obstante serem tidos, por muitos, como indesejáveis, não podem ser silenciados nos ambientes acadêmicos, campo este que deve permanecer o mais aberto possível, haja vista que "tudo isso fica ameaçado toda vez que se diz a um professor o que deve ou não deve ensinar, ou como ensinar o que lhe foi determinado". (DWORKIN, 2006: 404)

Ou seja, marca-se uma necessária distinção de outras instituições não acadêmicas, como, por exemplo, as diversas igrejas ou denominações religiosas presentes em nossas comunidades, ou outras associações que se pautam por visões singulares de vida e de mundo, nas quais pode-se decidir, com base na mesma ordem constitucional, não se discutir ou problematizar qualquer destes mesmos temas acima elencados.

Em resumo, limitações, desde que altamente necessárias, comprovadas nas situações específicas de concretização normativa, podem ser aplicadas, mas sempre a posteriori, jamais antes da liberdade acadêmica ser exercida, já que, do inverso, estaríamos caminhando ao encontro do estabelecimento não de responsabilizações legítimas, mas de censuras prévias, as quais, ressalte-se, são terminantemente vedadas pela Constituição de 1988, haja vista que impedem a livre circulação de informações, saberes e ideias, o que é, como já vimos, central em uma democracia constitucional.

A regra deve ser a liberdade de pesquisar, de criticar o posto e o esperado, sendo qualquer limite, exceção, devendo constituir, em realidade, condição de possibilidade da própria democracia, não mecanismo, ainda que indireto, de intimidação e silêncio. Ou seja, qualquer fronteira à liberdade acadêmica não pode ser estabelecida "ao gosto" de alguma autoridade qualificada, como uma instituição, um poder ou alguma maioria, nem tampouco pode implicar espaços imunes nos quais imperem "soberanos da verdade", ainda que altamente qualificados, o que marca a diferença entre censura e responsabilização, entre um espaço democrático e o ditatorial, ainda que este último apareça travestido de constitucional.

Uma situação em que muitos destes argumentos podem ser visualizados, ainda mais pela circunstância de que ocorreu em um regime de exceção, foi o Habeas Corpus 40.910/PE (1964), 
decidido pelo Supremo Tribunal Federal, no qual se afirmava haver um constrangimento ilegal à liberdade de expressão e de cátedra, como então configuradas na Constituição de $1946 .{ }^{8}$

Como se pode ler no relatório do caso, este dizia respeito a um professor da Faculdade de Ciências Econômicas da Universidade Católica de Pernambuco, que havia distribuído, aos seus alunos, um manifesto político em que tecia críticas ao momento político que atravessava o Brasil [a ditadura começava a ser implantada], sem fazer qualquer incitamento a prática de atos violentos.

O Ministro Hahnemann Guimarães, como relator, deferiu o pedido, concedendo a ordem de tolher a respectiva ação penal que havia sido instaurada contra o docente. No entendimento do então membro do STF, o manifesto distribuído refletia as posições políticas pessoais do professor, tecendo críticas desfavoráveis ao momento político, além de clamar aos seus estudantes que assumissem a sua "responsabilidade" pela defesa da liberdade e da democracia, sem, contudo, como já dito, fazer qualquer pedido de protestos de subversão violentos.

Por sua vez, o Ministro Evandro Lins e Silva, acompanhando o relator e também concedendo o Habeas Corpus, teceu uma série de argumentos que se basearam no pensamento constitucional estadunidense, principalmente em uma obra do juiz da Suprema Corte dos Estados Unidos, William Douglas, intitulada "The Right of the People". Foi deste livro, que o Ministro Lins e Silva, como se pode ler nas páginas 1314-1315 de seu voto, retirou uma passagem em que o juiz Douglas destacava que:

o governo não pode privar os cidadãos de qualquer ramo do conhecimento, nem impedir qualquer caminho para a pesquisa, nem proibir qualquer tipo de debate. A proibição se estende aos debates particulares entre os cidadãos, aos pronunciamentos públicos através de qualquer meio de comunicação ou ao ensino nas salas de aula [...] o espírito da livre pesquisa deve dominar nas escolas e universidades. (STF. Habeas Corpus No. 40. 910. Pernambuco)

Ora, foram tais parâmetros que nortearam todo o voto do Ministro Lins e Silva, em que a ênfase foi posta na liberdade de cátedra, de ensino, no potencial democrático de uma discussão liberta de amarras, do medo e do conformismo.

Já o Ministro Pedro Chaves, ainda que também concedendo o $H C$, acompanhando, "no campo absolutamente jurídico", o voto do relator, fez questão de marcar sua divergência, no "terreno político-ideológico", quanto aos argumentos expostos pelo Ministro Lins e Silva. Para o Ministro Pedro Chaves, a Constituição de 1946, então em vigor, não forneceria “meios de defesa

${ }^{8}$ Leia-se, in verbis: "Art 168 - A legislação do ensino adotará os seguintes princípios: VII - é garantida a liberdade de cátedra". 
às instituições nacionais" diante de prováveis abusos das liberdades ali garantidas, entre estas, a de cátedra. Em suas próprias palavras,

não podia ter passado pela cabeça de um constituinte, honestamente consciente das necessidades nacionais de transformar o direito de liberdade de cátedra em direito de incutir, no ânimo dos estudantes, ideias que são contrárias àquelas proclamadas pela Constituição. (STF. Habeas Corpus No. 40. 910. Pernambuco)

Outro voto que devemos recuperar foi o prolatado pelo Ministro Victor Nunes Leal, o qual, diga-se já, também acompanhou o relator e concedeu o Habeas Corpus. Em seu voto, o citado ministro salientou o "lado constitucional" dos debates ali travados, enfatizando um ponto que, no devido tempo, será por nós mais abordado, qual seja: “[...] o problema da liberdade de cátedra é muito mais importante, muito mais sério, do que o da liberdade de pensamento em geral”. (STF. Habeas Corpus No. 40. 910. Pernambuco)

Para isto, Nunes Leal foi ao cenário estadunidense, mais especificamente, ao caso, do ano de 1957, Sweezy v. New Hampshire, em que se discutiu a liberdade de cátedra, seu papel e possíveis limites. Neste caso, conforme se lê na interpretação do referido Ministro do STF, a Suprema Corte reconheceu que a academic freedom era um "princípio fundamental" da democracia norte-americana.

Fazendo um breve parêntesis, salientamos que o caso Sweezy ${ }^{9}$ é de enorme relevância, já que o mesmo foi decidido durante o período do perigo vermelho (red scare), de um mundo bipolar, de amigos e inimigos. Isto é, ainda que se movendo por um cenário de enorme histeria com o diferente, a Suprema Corte, em decisão tomada por maioria, problematizou os desafios postos a liberdade acadêmica por legislações restritivas, que se fundavam no medo do subversivo, construindo, ao final do julgamento, um espaço mais alargado de proteção desta mesma liberdade, diante de certas intervenções estatais.

Remetendo-nos diretamente ao caso citado pelo Ministro Nunes Leal, podemos ler que, na posição majoritária, a liberdade acadêmica detém ampla proteção constitucional, enfatizando que "liberties in the areas of academic freedom and political expression" eram "areas in which government should be extremely reticent to tread". (Sweezy v. New Hampshire, 1957)

\footnotetext{
${ }^{9}$ Aproveita-se para indicar que os casos mencionados no decorrer deste artigo, oriundos da Suprema Corte dos EUA, possuem como fonte o banco de dados dos sites da Cornell University Law School (Legal Information Institute) http://www.law.cornell.edu/supct/cases/topics/tog_freedom_of_speech.html, do United States Supreme Court Center, http://supreme.justia.com, além do http://www.oyez.org, referente ao The Oyez Project (últimos acessos em: 10/08/2016), salvo quando abordados diretamente por "terceiros".
} 
Com efeito, como destaca o Chief Justice Warren, o conhecimento "[...] cannot flourish in an atmosphere of suspicion and distrust. Teachers and students must always remain free to inquire, to study and to evaluate, to gain new maturity and understanding; otherwise, our civilization will stagnate and die". (Sweezy v. New Hampshire, 1957)

Dito isto, podemos ver que foi com base em muitos dos argumentos levantados, quando do julgamento em Sweezy, que o referido Ministro Victor Nunes Leal escreveu: “[...] não há criação, no mundo dos espíritos, sem liberdade de pensar, de pesquisar, de ensinar. Se há um lugar em que o pensamento deve ser o mais livre, este lugar é a universidade [...]”. (STF. Habeas Corpus No. 40. 910. Pernambuco)

Saliente-se que neste caso concreto, levado ao Supremo Tribunal Federal, refletindo o estado de espírito da época, houve um forte debate entre vários membros do Supremo Tribunal Federal, ainda que os mesmos tivessem votado, unanimemente, no sentido de conceder o habeas corpus. Destacaram-se as figuras dos Ministros Evandro Lins e Silva e Victor Nunes Leal que, ao decidirem que não havia qualquer justa causa para um processo penal contra o professor universitário, fizeram-no com um diálogo profundo com o pensamento norte-americano sobre o free speech e a academic freedom.

Esta linha, naquele contexto, conformava uma noção de liberdade de expressão e acadêmica em que a força problematizante do discurso demonstra toda a sua centralidade para o operar democrático, o que, por consequência, permite-nos, hoje, traduzir aquela pretendida restrição, como uma prévia das pesadas censuras que seriam, pouco depois, tornadas políticas de Estado. ${ }^{10}$

Com base em todos os argumentos até aqui colecionados, visualizamos que, em ambientes que se afirmam democráticos, não há liberdade acadêmica pela metade ou sujeita a restrições que pretendem, ao fim e ao cabo, não responsabilizar e fomentar ainda mais o aspecto discursivo do ato de conhecer, mas sim silenciar pela intimidação.

Percebe-se, assim, que liberdade acadêmica não é desejo de imunidade absoluta, já que este configuraria uma contradição em termos com os próprios pressupostos constitucionais por nós assumidos, mas também que reconhecer possíveis limites é bem diverso de abrir espaços para censuras, venham estas de onde vierem. Isto é, liberdade acadêmica implica que não

\footnotetext{
${ }^{10}$ Lembremos que, posteriormente, no ano de 1969 , estes dois ministros vivenciariam uma situação que demonstra, com enorme nitidez, a distinção entre uma "fronteira" legítima e uma abusiva "restrição", isto é, em razão de posições similares às assumidas no caso acima, tanto Evandro Lins e Silva, quanto Victor Nunes Leal, seriam "aposentados compulsoriamente", através de decreto que tinha como fundamento o Ato Institucional no.05/1968 (Al-5).
} 
precisamos de tutores que decidam, por nós, o que podemos, por exemplo, pesquisar, pois, concordando com Dworkin, o “Estado ofende seus cidadãos e nega a responsabilidade moral deles quando decreta que eles não têm qualidade moral suficiente para ouvir opiniões que possam persuadi-los de convicções perigosas ou desagradáveis". (DWORKIN, 2006: 319)

Em outras palavras, podemos denotar que liberdade acadêmica é para "cidadãos adultos” (DWORKIN, 2006: 319), imputáveis por suas ações, marcando, nas situações concretas e dentro de um devido processo legal, a possibilidade de responsabilizações por pretensões abusivas, o que é diverso da presença de algum "pai redivivo" que procura determinar, sem espaço para divergências, o que os seus "filhos impúberes" precisam saber para serem felizes. Ou seja, mais uma vez convergimos na direção de Dworkin, quando este argumenta que, “[...] nem o governante nem a maioria dos cidadãos [...] tem o direito de nos impedir de ouvir uma opinião por medo de que não estejamos aptos a ouvi-la e ponderá-la”. (DWORKIN, 2006: 319)

É esta linha argumentativa que nos permite iluminar um ponto importante, que é aquele apontado pelo Ministro Nunes Leal em seu voto no julgamento acima visto, qual seja: liberdade de expressão e acadêmica são extremamente próximas e interligadas, não excludentes, haja vista seus inúmeros pontos de contato durante a história de afirmação do constitucionalismo, mas, simultaneamente, desvelam ter campos de incidência protetivos distintos.

Deste modo, podemos anotar que a liberdade de expressão, como uma cláusula geral, permite-nos, sem amarras prévias, expor nossas opiniões, mas sua dimensão responsabilizatória seria, dentro de certos parâmetros, diversa daquela da liberdade acadêmica, tendo em vista o papel esperado desta e daqueles a quem está dirigida em um Estado Democrático de Direito. Isto é, ser fonte, por exemplo, de crítica a dogmas assentados pelas tradições, de pesquisas livres das modernas teocracias, de pensar e de permitir o fluir e o florescer do conhecimento ou, para apropriarmo-nos de um pensamento elaborado por Dworkin, de dificultar a solidificação de uma “cultura de homogeneidade intelectual”. (DWORKIN, 2006: 396)

Nesta linha, como observa outro professor estadunidense, David Rabban:

[...] constitutional academic freedom might even protect professors at both public and private universities from laws that would apply to other citizens. The owner of a movie theater could be punished for showing a film declared obscene by a jury in his community though protected by juries elsewhere, but a professor at the adjacent university might have an academic freedom right to show the same film in an advanced course on the regulation of mass media to make the intellectual point that the definition of obscenity involves close questions on which community standards vary. (RABBAN, 1999: 242) 
Daí, que a liberdade acadêmica, longe de ser um privilégio, revela ser, diríamos, uma espécie de obrigação funcional ${ }^{11}$, um direito-dever, implicando, até mesmo, maiores responsabilidades do que aquelas dos demais cidadãos. Ou seja, a liberdade de expressão geral é uma garantia fundamental de toda a sociedade, mas não uma imposição, pois possibilita, inclusive, a não expressão, a não participação discursiva, sendo um direito, ainda que alguns possam traduzi-la como dever cívico, comunitário ou algo do tipo.

Entretanto, na companhia de Juan-Ramón Capella, é importante sempre termos em mente que a liberdade de ensinar, pesquisar e aprender, não resulta em espaços dominados por professores-cidadãos acima de qualquer suspeita ou anjos que só labutam pelo amor ao conhecer, pois "como ocorre na botânica, muitas das espécies acadêmicas não são precisamente ‘boas': há também as nocivas, soporíferas, urticantes e até letais”. (CAPELLA, 2011: 51)

Dito de outro modo, liberdade e autonomia acadêmica emergem, por exemplo, como uma exigência profissional do docente, como um verdadeiro imperativo, não uma opção possível pelo silêncio ou abstenção, pois se espera que os professores e demais membros das academias persigam, continuamente, a construção compartilhada de saberes, o que, muitas vezes, impõe abraçar a problematização de temas contrários aos desejos das maiorias e dos governos de plantão. Ou seja, as características singulares presentes no campo acadêmico implicam uma normatividade diversa daquela encontrada na cláusula geral de expressão.

Socorrendo-nos, mais uma vez, dos pensamentos de Ronald Dworkin, vemos que "evidentemente, a liberdade acadêmica tem relação com um valor político mais geral e mais conhecido, que é a liberdade de expressão. [...] Porém, essa ideia deixa no escuro aquilo que a liberdade acadêmica tem de especial”. (DWORKIN, 2006: 394-395)

Para o mesmo Dworkin, este especial seria o fato de que "a liberdade de expressão, em essência, é o direito de ter alguma possibilidade de dizer algo, e não o direito de dizê-lo e continuar sendo sustentado e auxiliado por aqueles que consideram falsa ou indesejável a ideia pregada" (DWORKIN, 2006: 395). Ou seja, academic freedom impõe que "[...] certas instituições têm de continuar sustentando e apoiando certas pessoas independentemente do que estas possam falar, escrever ou ensinar", sendo, por tal aspecto, "mais forte do que o direito geral de liberdade de expressão". (DWORKIN, 2006: 395)

Vale dizer, a liberdade de expressão e a liberdade acadêmica não devem ser traduzidas como se fossem sinônimas, sob risco de perdermos o campo protetivo específico desta última,

\footnotetext{
${ }^{11}$ Ver: (RABBAN, 1999).
} 
pois se historicamente a liberdade acadêmica emerge das batalhas por liberdade de expressão, isto não significa que tenham o mesmo sentido, haja vista que esta liberdade reflete uma série de expectativas e responsabilidades que a singularizam.

Daí que o discurso acadêmico, o qual não se reduz, por exemplo, aos professores, não sendo uma garantia constitucional apenas deste grupo, já que inclui todos aqueles que se movem pelo universo do sistema de ensino superior, requer, predominantemente, uma alta dose de autonomia - não de soberania - tanto dos docentes, quanto dos alunos e da própria instituição, ou seja, há uma necessidade de certo grau de insulamento ou de autorrefência, por parte dos agentes deste espaço do conhecimento.

Neste sentido, como argumenta o lembrado Ronald Dworkin, esta liberdade acadêmica exigiria "dois níveis de isolamento", um da esfera política e do poder econômico, outro, que "isola os acadêmicos" da própria força administrativa institucional, ou seja, reconhece-se que um poder legislativo pode até ter a competência de decidir se cria ou não uma instituição de ensino superior, mas depois de optar por instalá-la, conformando sua estrutura orçamentária e organizacional, e até mesmo enfatizando o campo em que deverá atuar, não mais detém poder de configurar a forma como este projeto pedagógico e acadêmico será concretizado, como as disciplinas serão ministradas. Além disso, esta autonomia também deve existir internamente, isto é,

[...] a liberdade acadêmica isola os acadêmicos dos administradores da universidade: o reitor e o conselho podem nomear os professores, determinar o orçamento dos departamentos e assim decidir, dentro de certos limites, o currículo dos cursos; mas não podem decretar como os professores devem ensinar aquilo que se decidiu que devia ser ensinado. (DWORKIN, 2006: 393-394)

Esta exigência de um espaço não sujeito a interferências desnecessárias ao seu próprio operar, que não fomentam o ensino e a aprendizagem, desvela uma tensão constitutiva, pois, em muitos momentos, o sentido do que seja ensino superior em democracias colocará em conflito alunos e docentes, além das próprias instituições.

Contudo, este conflito, típico de um ambiente que se abre às novidades e às mais plurais investigações, fundado em interações dialógicas, ao invés de ser contraproducente, demonstra ser pressuposto da própria noção moderna de liberdade acadêmica, pois assume que não há, nesta seara, um só modo de ensinar e de aprender, não havendo aquele "um" que tudo sabe e pode.

Nesse sentido, as interações entre as dimensões do ensinar e aprender, em um meio que potencializa a crítica, são tensionais, mas não excludentes. Em realidade, pressupõem-se, ao 
menos em um Estado Democrático de Direito, o que, mais uma vez, desvela que intervenções externas que buscam elidir esta tensão podem ser extremamente silenciadoras, já que não surgem de um debate entre os participantes e destinatários da liberdade acadêmica, sendo impostas de cima.

Reforçamos, aqui, que a defesa da autonomia acadêmica, da liberdade de não ser intimidado por intervenções externas, daquilo que a doutrina estadunidense denomina de extramural political interference (BYRNE, 1989: 295), em virtude das pesquisas que realiza, das palestras e aulas que ministra, ou dos grupos de estudo que participa, não resulta em um campo imune a responsabilizações. Tais responsabilizações devem, quando relacionadas com as atividades acadêmicas, mesmo quando exercidas ou proferidas fora do espaço físico acadêmico, serem aferidas, predominantemente, internamente, o que impõe um campo de incidência normativo diverso da liberdade de expressão geral.

In this way, then, academic freedom speaks directly and distinctly to the special critical role of the professional teacher and scholar. He is encouraged in the development of all of his academically related activities to ply a bold and innovative critical acumen. On the other hand, he is accountable to those who share a like duty and a similar commitment as his own, to answer at a professional level for the ethical integrity of his work so to establish by the fact of that integrity that he fully justifies the contingent privilege of academic freedom which he has claimed. (VAN ALSTYNE, 1972: 150)

Em outras palavras, pensemos em uma situação que envolva um pesquisador que investiga o impacto de novos medicamentos em determinadas doenças. Ora, sujeitar os resultados de tal pesquisa a juízos externos, realizados por pessoas que não possuem qualificação especifica, por exemplo, para compreender as metodologias empregadas, esvazia a própria concepção de liberdade acadêmica. Também podemos considerar casos em que sociólogos e antropólogos, após amplos estudos, defendem que certos agrupamentos humanos merecem uma abordagem mais protetiva por parte do poder público. Não seria deturpar, assim como na primeira situação, a liberdade acadêmica, sujeitar estes trabalhos a interferências extra muro?

Dentro desta mesma linha, entendemos que não está inserido no campo da liberdade acadêmica uma situação em que, por exemplo, um professor de física ou botânica concedesse uma entrevista afirmando que o holocausto, ocorrido na Segunda Grande Guerra, não existiu. Nesta situação, o que deveria ser questionado não era se houve ou não um abuso da liberdade acadêmica, mas, sim, da liberdade de expressão, a qual implica um juízo diverso da primeira, já 
que não vinculada a aferir se teria ocorrido uma incompetência ou negligência profissional, sendo as prováveis sanções, deslocadas da averiguação da integridade e da ética acadêmica, em si mesmas consideradas. ${ }^{12}$

Em suma,

[...] academic freedom does not insulate speakers from being penalized for the content of their speech. Academic freedom only requires that speakers be evaluated by their peers for relative professional competence and within the procedural restraints of the tenure system [estabilidade funcional]. (BYRNE, 1989: 283)

Destas posições é que decorreria a necessidade do discurso acadêmico enunciado estar, de alguma forma, relacionado com as atividades e responsabilidades que integram o universo do ensino superior, ou seja, liberdade acadêmica não se confundiria com a liberdade de expressão em virtude da primeira estar vinculada a algum tipo de expertise, da produção e circulação de conhecimento, não de mera opinião. Ou seja, concordando com certa linha de pensamento estadunidense $^{13}$, entendemos que esticar em demasia a liberdade acadêmica pode levar à desnaturação da especificidade protetiva desta, tornando, por exemplo, a problematização sobre intervenções nesta seara desnecessária, já que tais intervenções seriam tratadas pela cláusula geral da livre expressão, desconsiderando o seu singular contexto de aplicação.

Não se nega, como já deve ter ficado claro, que a história das lutas por afirmação da liberdade de expressão é essencial na compreensão da liberdade acadêmica, mas estas linhas de convergência não implicam que possuem o mesmo campo de incidência, haja vista que as peculiaridades que cercam a liberdade acadêmica exigem uma normatividade não presente nas relações gerais configuradas pela liberdade de expressão.

Por exemplo, um professor, salvo comprovada incompetência e inconsistência, pode posicionar-se sobre temas que perpassam sua esfera de atuação, sem receio de ser punido por tais posicionamentos, ainda que estes critiquem ou questionem a própria instituição pública de ensino que estejam vinculados ou, mesmo, os departamentos e ministérios governamentais que porventura tenham algum vínculo orçamentário ou administrativo com as instituições de ensino, haja vista que é isto que se espera de sua prática, de sua profissão.

Ora, este tipo de proteção profissional não é um imperativo em outras atividades, nem está presente quando o mesmo professor se coloca para além de suas pesquisas e estudos, sendo

\footnotetext{
${ }^{12}$ Cf.: (RABBAN, 1999: 242-243) e (VAN ALSTYNE, 1972: 147-149).

${ }^{13}$ Ver, neste sentido: (RABBAN, 1999) e (VAN ALSTYNE, 1972). Divergindo, construindo uma concepção mais alargada da academic freedom, temos: (SEARLE, 1971).
} 
os possíveis questionamentos, sanções e responsabilizações decididos a partir da análise das pretensões concretas levantadas diante da liberdade de expressão, o que demonstra que a liberdade acadêmica não é um privilégio pessoal nem institucional, mas uma necessidade decorrente da própria concepção moderna do ensino superior.

Com efeito, por não ser um privilégio de alguma casta esclarecida, é que a liberdade acadêmica destina-se, primordialmente, à integridade das atividades de cunho acadêmico, da crítica dissolvente, mas fundamentada, isto é, o princípio da liberdade acadêmica

protects the knowledge-seeking activities of the university, and thus offers the aggrieved individual no protection when the professor or student is sanctioned for action or speech that falls beyond the knowledge-seeking activities of the university [...]. That individual stands before the court as a citizen and has rights as a citizen, but he is not acting as a professor or student and thus receives no protection from the principle of academic freedom. (FISS, 2013: 750)

Esta argumentação possibilita iluminar um ponto central na busca da compreensão do alcance normativo da liberdade acadêmica em nosso ordenamento constitucional. Tal ponto refere-se ao fato de já podermos visualizar o que esta liberdade fundamental não é, o que impõe, por consequência, refletir sobre suas fronteiras. Isto é, qualquer liberdade constitucional só adquire legitimidade em termos dialógicos, na possibilidade de divergências, não podendo operar como mecanismo de exclusões estereotipadas, como um instrumento fossilizador do pensar, revelando que limites devem sempre operar como condição de possibilidade deste mesmo espaço plural e dialogicamente estruturado.

Assim, a liberdade acadêmica, não obstante, tradicionalmente, ser pensada a partir da posição do corpo docente, a este não se reduz, ao menos em democracias constitucionais, pois também os alunos e a instituição possuem seus próprios campos de incidência, em que só nos casos concretos a legitimidade ou não de pretensões apresentadas podem ser analisadas e decididas. Ou seja, "constitutional academic freedom, despite tensions between its individual and institutional components, can protect universities without sacrificing professors" (RABBAN, 1999: 301) e, diríamos nós, também sem sacrificar os alunos e sua liberdade de crítica diante do ensinado.

Portanto, verificamos que o sentido e o alcance da liberdade acadêmica desloca-se por cenários tensos e complexos, sempre em disputa entre fechamentos e aberturas, refletindo o fato de que as "definitions of academic freedom have developed in response to actual historical circumstances”. (RABBAN, 1999: 229) 


\section{ACADEMIC FREEDOM: APONTAMENTOS ESTADUNIDENSES ${ }^{14}$}

As considerações acima elencadas impõem, ainda que com todos os riscos que recortes epistemológicos carregam, que busquemos pontuar algumas questões presentes no cenário estadunidense, já que neste os debates, tanto acadêmicos, quanto jurisdicionais, apresentam-se em um estágio mais profundo. Contudo, esta mesma profundidade determina que uma série de indagações lá levantadas e discutidas sobre liberdade acadêmica não poderão ser aqui devidamente investigadas, permanecendo abertas para futuras análises que pretendemos empreender.

Com esta ressalva, podemos colocar que nosso recorte enfatizará alguns argumentos expostos em decisões sobre o alcance da academic freedom, ocorridas durante o período da chamada Guerra Fria, ou seja, do medo e ódio ao diferente.

Sendo assim, decidimos partir do caso nomeado Adler v. Board of Educantion of City of New York, de 1952. Neste, em breves palavras, a Supreme Court teve que enfrentar a questão da constitucionalidade de legislação do Estado de Nova York que dispunha sobre sanções a professores das escolas públicas daquele estado que tivessem tido algum vínculo com organizações taxadas como "subversive organizations", não sendo aprovados nos citados juramentos de lealdade.

Foi um destes juramentos que alguns professores decidiram enfrentar, recusando-se a participar destes tristes espetáculos, alegando a inconstitucionalidade de tais normativas estaduais, conseguindo, em um primeiro momento, ter suas pretensões reconhecidas na esfera estadual. Contudo, a Corte Federal de Apelação (Court of Appeals of New York) reverteu a decisão inicial, afirmando que a legislação nova-iorquina não afrontava direitos fundamentais dos professores.

Por causa deste entendimento da Court of Appeals, foi realizado um apelo a Supreme Court, sempre com fundamento que as liberdades de expressão e reunião estariam sendo injustificadamente atacados e reduzidos pela legislação de Nova York. Mas esta interpretação não prevaleceu na Suprema Corte, pois a maior parte dos seus juízes decidiu que não haveria qualquer inconstitucionalidade na legislação nova iorquina que estabelecia a exigência dos

${ }^{14}$ Para uma visão geral da academic freedom no cenário estadunidense, ver: (EUBEN, 2002), e (LEVINSON, 2007) e (SCHAFFER, 2014). 
juramentos, não revendo o decidido pela Corte de Apelação, ou seja, não se atendeu ao pedido dos professores.

Para a maioria dos justices, não teria ocorrido nenhuma ofensa à liberdade de expressão ou ao direito de associação, já que aos professores tinha sido garantida a possibilidade de optar entre ensinar nas escolas públicas ou militar em grupos tipificados como subversivos ao governo estabelecido.

Como escreve o juiz Minton, redigindo a opinião majoritária, uma pessoa, submetida as disposições da citada legislação nova-iorquina, não teria denegado seu "right of free speech and assembly", haja vista que sua "[...] freedom of choice between membership in the organization and employment in the school system might be limited", tendo em vista o dever que o Estado possui de garantir um ambiente escolar livre de ideias subversivas. (Adler v. Board of Educ. of City of New York, 1952)

Visualiza-se, nos argumentos vencedores, que a circunstância de um professor ter tido contato com organizações marcadas como subversivas, bastava para o mesmo ser recusado ou afastado das escolas públicas, pois supunha-se que este não estaria ensinando, mas sim fazendo propaganda, doutrinando as crianças e os jovens, abusando de sua posição de autoridade, o que justificaria a exigência de averiguação de sua fidelidade por parte das autoridades constituídas, visando, com este procedimento, manter a integridade das escolas (maintain the integrity of the schools as a part of ordered society), já que "from time immemorial, one's reputation has been determined in part by the company he keeps". (Adler v. Board of Educ. of City of New York, 1952)

Todavia, as posições que decidimos enfatizar não são aquelas que embasaram a maioria vencedora, mas sim os argumentos expostos nos votos minoritários, pois entendemos que são estes que confluem com a concepção de democracia constitucional que assumimos e que guia nosso trajeto de análise, já que estas posições indicariam uma interpretação constitucionalmente adequada do alcance normativo da liberdade de ensinar e aprender, em última instância, da liberdade acadêmica.

De início, tomemos a seguinte passagem do Justice Black, refletindo sobre as disposições legislativas que estavam tendo sua constitucionalidade questionadas em Adler: “This is another of those rapidly multiplying legislative enactments which make it dangerous - this time for school teachers - to think or say anything except what a transient majority happen to approve at the moment". (Adler v. Board of Educ. of City of New York, 1952, Justice Black, dissenting) 


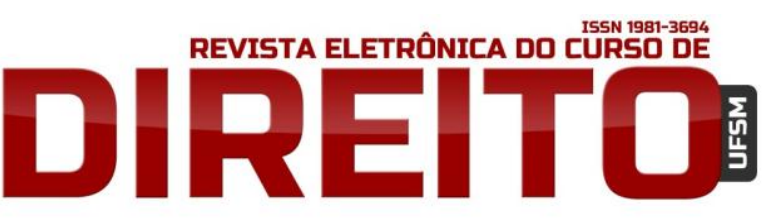

LIBERDADE ACADÊMICA EM TEMPOS DIFÍCEIS: DIÁLOGOS BRASIL E ESTADOS UNIDOS

MARCELO ANDRADE CATTONI DE OLIVEIRA MARIA FERNANDA SALCEDo REPOLÊS Francisco de CASTILHo PRATES

Desta emerge a dimensão contramajoritária que a liberdade fundamental aqui abordada carrega consigo, a qual não pode, para cumprir seu papel crítico, estar subordinada aos desejos de maiorias morais, de standards homogeneizantes de ensino e aprendizagem. 0 risco em tais escolhas legislativas seria tornar o ato de conhecer estático e fechado, tornando o legislador uma espécie de mestre dos mestres, onisciente e onipresente em todas os ambientes escolares, único autorizado a decidir quais ideias e concepções de mundo poderiam circular e quais não eram necessárias a produção do conhecimento. Isto é, haveria uma interdição e ossificação da busca na construção dos saberes.

Em suma, como anota o mesmo juiz Black, "public officials with such powers are not public servants; they are public masters". (Adler v. Board of Educ. of City of New York, 1952, Justice Black, dissenting)

Por sua vez, o juiz Douglas, também divergindo da maioria, salientou que leis restritivas, como aquelas do Estado de Nova York, voltadas a manter as escolas livres de influências subversivas (keeping the school free of 'subversive influences'), estariam, em realidade, estabelecendo um sistema de censura, o qual ofenderia o arcabouço constitucional estadunidense. (Adler v. Board of Educ. of City of New York, 1952, Justice Douglas, dissenting)

$\mathrm{Na}$ leitura do voto do juiz Douglas verifica-se o seu receio de ver implementado um sistema de vigilância autoritário, padronizador, um real estado policial (police state), cerceando os professores, os quais teriam que, a todo o tempo, provar sua lealdade a este Estado, ou seja, "the principals become detectives; the students, the parents, the community become informers". (Adler v. Board of Educ. of City of New York, 1952, Justice Douglas, dissenting)

Posto isto, saímos de Adler e vamos a Keyishian v. Board of Regents, a janeiro de 1967, no qual também se discutiu a validade constitucional das mesmas normas do Estado de Nova York que exigiam, como antes salientado, a demonstração inequívoca de lealdade de servidores públicos, entre estes, dos professores da universidade estadual, diante de ideias consideradas subversivas.

Assim como em Adler, também neste caso alguns professores da State University of New York, recusaram-se a declarar, formalmente, que não eram e nem tinham sido, membros de organizações taxadas como subversivas e, por esta razão, ou não tiveram seus contratos renovados ou foram demitidos. Isto é, esta recusa em participar de alguns estágios da aferição de sua lealdade, foi o estopim para sofrerem represálias advindas da legislação estadual. 
Também aqui, os atingidos pelas normas de Nova York recorreram ao Judiciário, defendendo a tese de que esta inabilitação, por deslealdade, para o ensino universitário era inconstitucional, ofendendo seus direitos de livre expressão e de associação.

Já refletindo o momento histórico da busca por maior distensão política, uma Suprema Corte, registre-se, por mínima maioria ${ }^{15}$, decidiu, desta vez, acatar o apelo dos professores, entendendo que a legislação nova-iorquina, que conformava o programa de lealdade na seara do ensino público (New York teacher loyalty plan) ofenderia as liberdades elencadas na Primeira $E$ menda ${ }^{16}$, afirmando que, a liberdade acadêmica é uma "[...] special concern of the First Amendment, which does not tolerate laws that cast a pall of orthodoxy over the classroom". (Keyishian v. Board of Regents, 1967)

O que sobressai da opinião majoritária, redigida pelo juiz Brennan, é a preocupação daquilo que, no contexto estadunidense é conhecido como chilling effect ${ }^{17}$, o impacto resfriador que podem emergir de interferências estatais na seara das liberdades fundamentais, entre as quais encontra-se a de ensinar, pesquisar e publicar, o que impunha, na posição adotada pela maioria, que estas intervenções estatais devam ser interpretadas de modo preciso e limitado (narrow), sob pena de atuar como mecanismos inibidores, por exemplo, da liberdade acadêmica, afrontando, desta maneira, a Primeira Emenda.

Foi tal linha argumentativa que levou Brennan a escrever uma passagem que é sempre recuperada quando se analisa a liberdade acadêmica nos Estados Unidos, qual seja:

Our Nation is deeply committed to safeguarding academic freedom, which is of transcendent value to all of us, and not merely to the teachers concerned. That freedom is therefore a special concern of the First Amendment, which does not tolerate laws that cast a pall of orthodoxy over the classroom. (Keyishian v. Board of Regents, 1967)

Ainda que apresentados rapidamente, inclusive reconhecendo que outros pontos presentes nos caminhos que levaram as decisões aqui trabalhadas poderiam ser salientados,

\footnotetext{
${ }^{15}$ Os votos minoritários entenderam que o Estado, através dos seus braços legislativos poderiam construir e aplicar leis como as de Nova York, não admitindo que as mesmas fossem muito vagas ou imprecisas, considerando, deste modo, que não havia nenhuma inconstitucionalidade presente. (Keyishian v. Board of Regents, 1967, Justice Clark, dissenting)

${ }^{16}$ First Amendment. Freedom of Religion, Press, Expression. Ratified 12/15/1791. "Congress shall make no law respecting an establishment of religion, or prohibiting the free exercise thereof; or abridging the freedom of speech, or of the press; or the right of the people peaceably to assemble, and to petition the Government for a redress of grievances."

${ }^{17}$ Conferir: (YOUN, 2013).
} 
além de que outros cases que poderiam ser abordados $^{18}$, podemos entender o porquê da centralidade dos argumentos vencidos em Adler e as posições vencedoras que guiaram o decidido em Keyishian na história da liberdade acadêmica no cenário dos Estados Unidos, haja vista que estes alçaram os debates a um parâmetro constitucional, problematizando os chamados juramentos de lealdade e seus impactos nas atividades de ensino e aprendizagem, demonstrando a centralidade da academic freedom para um Estado de Direito que afirma-se democrático e constitucional.

Em outras palavras, estas posições realçaram o fato de que assuntos acadêmicos devem primordialmente, serem decididos sem interferências externas, sob o risco, ainda maior, de estarmos abrindo espaços para silenciamentos inquisitoriais, como os incontáveis Galileus $e$ Giordanos, presentes em vários momentos infelizes de nossa história, não nos deixam esquecer. $^{19}$

Deste modo, e não obstante uma série de indagações que poderiam ser levantadas ${ }^{20}$, assumimos, com fundamento nas posições argumentativas que enfatizamos nos casos acima tratados, que:

Academic freedom protects those whose thinking challenges orthodoxy; at the same time the legitimacy of the challenge - the proof that the critic is not a madman or a crank - is secured by membership in a disciplinary community based upon shared commitments to certain methods, standards, and beliefs. (SCOTT apud AREEN, 2009: 960)

De tudo o exposto, e apropriando-nos, livremente, de uma das célebres figuras construídas pelo juiz da Suprema Corte estadunidense, William Brennan, a parti da qual podemos visualizar que a liberdade acadêmica, como qualquer das liberdades fundamentais em um Estado Democrático de Direito, para florescer e realizar as tarefas que dela se esperam, necessita do mais amplo, mas não imune e ilimitado, espaço para respirar (breathing space) ${ }^{21}$,

\footnotetext{
${ }^{18}$ Citamos, entre tantos outros: (Wieman v. Updegraff, 1952), (Slochower v. Board of Higher Education of New York City, 1952), (Shelton v. Tucker, 1960), (Regents of the University of Michigan v. Ewing, 1985) e (Garcetti v. Ceballos, 2006).

${ }^{19}$ A nossa referência é clara e direta à vida dos pensadores Giordano Bruno e Galileu Galilei, ambos, com suas especificidades, perseguidos e condenados por pensarem de modo diverso das forças então dominantes.

${ }^{20}$ Tomemos os debates sobre concepções de liberdade acadêmica individual e aquelas que enfatizam a proteção institucional (HORWITZ, 2007), além de outras, com que tendemos a concordar, que entendem que estas dimensões não são excludentes, mas pressupõem-se (RABBAN, 1999). Há também os debates desta liberdade ser intra ou extramuros, se abarcaria discursos diretamente profissionais ou também não profissionais (VAN ALSTYNE, 1972), se seria ou não um subsistema da liberdade de expressão. (DWORKIN, 2006: 390-415)

${ }^{21}$ Ver: NAACP v. Button, 1963.
} 
em que este locus, seus limites e condições de possibilidade, emerge como reflexo da força normativa do pluralismo, do diálogo entre diversas e iguais singularidades, ou seja, do já lembrado patriotismo constitucional.

\section{CONCLUSÃO}

O que esta reconstrução, ainda que apresentada, em vários momentos, de modo sintético, pode auxiliar-nos na compreensão de iniciativas como, por exemplo, os projetos de lei das chamadas escolas sem partido?

De saída, podemos apontar o que não é liberdade de cátedra. Não é para humilhar, ofender ou desconhecer a liberdade de aprender, da crítica potencial que pode advir dos estudantes, que, em uma democracia constitucional, não são objeto, mas sim sujeitos ativos de seu próprio processo de conhecimento, em que ensinar e aprender não são dimensões que se excluem, mas ao contrário, pressupõem-se, ainda que em tensão, ou seja, os estudantes “[...] should be viewed not as passive vessels but rather as active participants in the process through which opinions and beliefs are tested and knowledge revealed. They speak back in class, often challenging the day's lecture, and they also undertake research projects". (FISS, 2013: 736)

Assim, a linha argumentativa que nos guiou busca demonstrar que o campo de incidência protetivo da liberdade acadêmica, em democracias constitucionais, não é sinônimo de imunidades absolutas, mas sim que a aferição de possíveis abusos relacionados as atividades acadêmicas sejam norteados, predominantemente, por procedimentos internos, entre pares com a exigida qualificação para analisar as pretensões levantadas nos casos concretos, não externas e apriorísticas censuras.

Como dito acima, se, por exemplo, um professor de história afirma que o holocausto judaico foi uma "invenção do sionismo internacional", ou que publica artigos colocando que a "escravidão" não foi tão perversa aos afrodescendentes, ele não poderia se apoiar em sua liberdade acadêmica, pois esta possibilita que, em situações limites como as hipoteticamente aqui erigidas, quando demonstrada uma enorme incompetência funcional, o professor possa ser sancionado academicamente, já que haveria um claro desvirtuamento de sua fala, a qual estaria para além da liberdade acadêmica. 
Em outras palavras, a liberdade de cátedra e a autonomia acadêmica não estão reduzidas ao espaço físico dos muros das instituições de ensino superior, mas sim às suas relações com as falas acadêmicas, com as pesquisas realizadas, com as áreas de interesse que os estudantes e professores trabalham. Sendo assim, se um professor que constrói sua carreira analisando, por exemplo, as relações sindicais e os movimentos coletivos do direito do trabalho, não pode ser punido, ao menos em uma democracia constitucional, por atividades que levem o mesmo a aproximar-se dos sindicatos e movimentos sociais, já que estaria coberto não pela liberdade de expressão, mas sim pelas singularidades que marcam e definem a dimensão da liberdade acadêmica.

Esta distinção, não um privilégio pessoal ou institucional, decorre da circunstância de a liberdade acadêmica, sua exigência de autonomia, não de soberania, vincula-se à dimensão do ensino/aprendizagem, da pesquisa e extensão, a crítica qualificada, livre e não intimidada, isto é, esta liberdade fundamental relaciona-se a situações mais específicas, especializadas e singulares, o que, como visto, exige algum tipo de estabilidade funcional para operar, diferenciando-a, assim, da liberdade de expressão, mais genérica e ampla.

Outro ponto que sobressai, a partir do árduo processo histórico de busca por afirmação desta liberdade fundamental, principalmente em tempos difíceis, como foram a ditadura no Brasil e o macarthismo nos Estados Unidos, é que não se deve confundir uma exigência de objetividade com neutralidade no campo do ensino, haja vista que, por exemplo, os infelizes juramentos de lealdade, nada tinham de neutro. Isto é, a própria defesa da neutralidade não é neutra, revelando ser a defesa de uma dada opção política, entre outras, presentes na sociedade.

Desta maneira, espera-se que os docentes, pesquisadores e alunos possam ministrar suas aulas, realizar suas pesquisas e contribuir no processo de aprendizagem de modo livre, ainda que dentro de padrões e programa gerais das disciplinas, sendo a diversidade de visões, interpretações e traduções de mundo, a marca central do moderno embate acadêmico, em que o desejo de pretensas e inatingíveis neutralidades soando como persistentes anacronismos.

Assumindo as conclusões até aqui construídas, entendemos que projetos de lei, hoje em discussão em nosso Congresso Nacional, que propõem, entre outros pontos, tipificar o "assédio ideológico", quase um assédio intelectual, limitando o campo de atuação dos docentes e, por via transversa, também a área de aprendizagem dos alunos, ou buscando edificar uma "escola sem partido", ressoam como inconstitucionais, pois afrontariam toda uma série de princípios centrais ao nosso ordenamento constitucional, os quais revelam que democracia não é redutível 
ao desejo das maiorias, pois implica também o respeito e a garantia aos direitos das minorias, ao direito de divergir.

Ora, uma nota técnica, emitida em julho de 2016, pela Procuradoria Federal dos Direitos do Cidadão, assinada pela ilustre Procuradora Deborah Duprat, parece também caminhar neste sentido, haja vista que, ao analisar a citada proposta de "escola sem partido", ainda que esta proposta não trate, diretamente, da liberdade acadêmica, anota que o referido projeto de lei "[...] coloca o professor sob constante vigilância, principalmente para evitar que afronte as convicções morais dos pais", o que conformaria, de saída, sua inconstitucionalidade". (Nota Técnica 01/2016 - Procuradoria Federal dos Direitos do Cidadão/PFDC, sp)

$\mathrm{Na}$ mesma nota, pode-se ler que a noção de uma suposta "neutralidade ideológica", presente no projeto de lei ora analisado, é, por si só, “absurda”, já que não há ideologia neutra", haja vista que

um poder dominante pode legitimar-se envolvendo pelo menos seis estratégias diferentes: promovendo crenças e valores compatíveis com ele; naturalizando e universalizando tais crenças de modo a torná-las óbvias e aparentemente inevitáveis; desqualificando ideias que possam desafiá-lo; excluindo formas rivais de pensamento; e obscurecendo a realidade social de modo a favorecê-lo. (Nota Técnica 01/2016 - Procuradoria Federal dos Direitos do Cidadão/PFDC, sp)

$\mathrm{Na}$ interpretação da Procuradoria Federal dos Direitos do Cidadão, o que fundamentaria o projeto de lei que busca instalar o programa "escola sem partido", seria, entre outros argumentos, o “[...] inconformismo com a vitória das diversas lutas emancipatórias no processo constituinte; com a formatação de uma sociedade que tem que estar aberta a múltiplas $e$ diferentes visões de mundo", o que contrariaria a vigente ordem constitucional, já que ofenderia, por exemplo, a livre circulação pluralista de ideias e concepções pedagógicas, além de negar a liberdade de cátedra e a possibilidade ampla de aprendizagem.

Este posicionamento só corrobora o que toda nossa reconstrução procurou desvelar, que é o fato de que liberdade acadêmica, independência de pensar, de julgar os caminhos deste mesmo pensar, choca-se, profundamente, com tentativas de impor algum tipo de unidade substancial e monolítica, haja vista que ninguém ou nenhuma instituição de ensino pode cumprir suas árduas tarefas com uma espada sobre a cabeça, ainda mais quando assumimos que os simultâneos e interdependentes atos de pesquisar/aprender/ensinar não realizam-se através de lacônicos comunicados. 


\section{REFERÊNCIAS}

ANTEPROJETO CONSTITUCIONAL 'AFONSO ARINOS'. In: Anais da Assembleia Constituinte. Suplemento Especial, Sexta-Feira, 26 de Setembro de 1986. Disponível em: <http://www.senado.gov.br/publicacoes/anais/constituinte/AfonsoArinos.pdf>. Acesso em: 02 jul. 2016.

APTHEKER, Herbert. The Era of McCartyism: First Published as History and Reality. New York: Marzani \& Munsell, 1962.

AREEN, Judith. Government as Educator: A New Understanding of First Amendment Protection of Academic Freedom and Governance. In: The Georgetown Law Journal. Vol. 97, 2009, pp. 9451000. Disponível em: <http://papers.ssrn.com/sol3/papers.cfm?abstract_id=1291922>. Acesso em: 15 jun.2016.

BRASIL. Constituição dos Estados Unidos do Brasil (1946). Disponível em: <http://www.planalto.gov.br/ccivil_03/Constituicao/Constituica046.htm>. Acesso em: 15 jul. 2016.

BRASIL. Supremo Tribunal Federal. Habeas Corpus 40.910. Pernambuco. Relator: Ministro Hahnemann Guimarães. 1964. Disponível em:

<http://redir.stf.jus.br/paginadorpub/paginador.jsp?docTP=AC\&doclD=57711>. Acesso em: 15 nov.2013.

BRASIL. Projeto de Lei da Câmara N 1411/2015. Tipifica o crime de Assédio Ideológico e dá outras providências. Disponível em:

<http://www.camara.gov.br/proposicoesWeb/prop_mostrarintegra;jsessionid=19E5E524564DC07 64D8B7BE98F678ECA.proposicoesWeb1?codteor=1330054\&filename=PL+1411/2015>. Acesso em: 11 jul. 2016.

BRASIL. Projeto de Lei do Senado (PLS) No 193/2016. Inclui entre as diretrizes e bases da educação nacional, de que trata a Lei n 9.394, de 20 de dezembro de 1996, o "Programa Escola sem Partido". Disponível em:

<https: / / www12.senado.leg.br/ecidadania/visualizacaomateria?id=125666>. Acesso em: 15 jul. 2016.

BRASIL. Ministério Público Federal. Procuradoria Federal dos Direitos do Cidadão (PFDC). Nota Técnica 01/2016. Brasília. 21 de julho 2016. Disponível em:

<http://pfdc.pgr.mpf.mp.br/temas-de-atuacao/educacao/saiba-mais/proposicoes-

legislativas/nota-tecnica-01-2016-pfdc-mpf>. Acesso em: 05 ago. 2016.

BYRNE, Peter. Academic Freedom: A 'Special Concern of the First Amendment'. In: The Yale Law Journal. Vol. 99, No. 02, November, 1989, pp. 251-340. Disponível em:

<http://scholarship.law.georgetown.edu/facpub/1579>. Acesso em: 01 jul. 2016. 
CATTONI DE OLIVEIRA, Marcelo Andrade. Comentário ao art. $1^{\circ}$, parágrafo único. In: CANOTILHO, J.J. Gomes; MENDES, Gilmar F.; SARLET, Ingo; STRECK, Lenio. (Orgs.). Comentários à Constituição do Brasil. São Paulo: Saraiva/Almedina, 2013, pp. 137-140.

CORNELL UNIVERSITY. Legal Information Institute. Disponível em:

<http://www.law.cornell.edu/supct/cases/topics/tog_freedom_of_speech.html>. Acesso em: 10 ago.2016.

DWORKIN, Ronald. 0 direito da liberdade: a leitura moral da Constituição norte-americana. Trad. Marcelo Brandão Cipolla. São Paulo: Martins Fontes, 2006.

EUBEN, Donna R. Academic Freedom of Individual Professors and Higher Education Institutions: The current legal landscape. In: American Association of University Professors. May, p. 01-34, 2002. Disponível em: <https://www.aaup.org/issues/academic-freedom/professors-andinstitutions>. Acesso em: 07 jul. 2016.

FISS, Owen M. The Democratic Mission of the University. In: Albany Law Review. Vol. 76.1, p.735-752, 2013. Disponível em: <http://digitalcommons.law.yale.edu/fss_papers/4800>. Acesso em: 12 jun. 2016.

FREIRE, Paulo. Educação como prática da liberdade. 13.ed. Rio de Janeiro: Paz \& Terra, 1982.

HORWITZ, Paul. Universities as First Amendment Institutions: Some Easy Answers and Hard Questions. In: Notre Dame Legal Studies Research Paper. No. 07-18, p.01-76, 2007. Disponível em: <http://ssrn.com/abstract=966312>. Acesso em: 01 jul. 2016.

HOSHINO, Camilla (Brasil de Fato). Professora da rede pública é afastada ao abordar Marx em sala de aula. Revista Forum. 08 julho 2016. Disponível em:

<http: / / www.revistaforum.com.br/2016/07/08/professora-da-rede-publica-e-afastada-aoabordar-marx-em-sala-de-aula/>. Acesso em: 02 jul. 2016.

LEVINSON, Rachel. Academic Freedom and the First Amendment - Presentation to the AAUP Summer Institute. In: American Association of University Professors (AAUP). July, p. 01-21, 2007. Disponível em: <https://www.aaup.org/our-work/protecting-academic-

freedom/academic-freedom-and-first-amendment-2007>. Acesso em: 10 jun. 2016.

MADER, Helena. Deputada evangélica pede "providências legais" contra professor que tratou sobre homofobia em sala de aula. Correio Braziliense (Blogs). 05 julho 2016. Disponível em: <http: / /blogs.correiobraziliense.com.br/cbpoder/deputada-evangelica-pede-providenciaslegais-contra-professor-que-tratou-sobre-homofobia-em-sala-de-aula/>. Acesso em: 08 jul.2016.

MEYER-PFLUG, Samantha Ribeiro. Liberdade de Expressão e Discurso do Ódio. São Paulo: Revista dos Tribunais, 2009.

MORRIS, Arval A. Academic Freedom and Loyalty Oaths. In: Law and Contemporary Problems. Vol. 28, Summer, p.487-514, 1963. Disponível em:

<http://scholarship.law.duke.edu/lcp/vol28/iss3/4>. Acesso em: 02 jul.2016. 
OYEZ PROJECT. Oyez Project/Chicago-Kent College of Law. Disponível em:

<http://www.oyez.org>. Último Acesso em: 10 ago.2016.

PRATES, Francisco de Castilho. As fronteiras da liberdade de expressão no estado democrático de direito: o desafio de falas que oprimem, de discursos que silenciam. (Doutorado em Direito) - Faculdade de Direito da Universidade Federal de Minas Gerais (UFMG), Belo Horizonte, 2015.

RABBAN, David M. A Functional Analysis of "Individual" and "Institutional" Academic Freedom under the First Amendment. In: Law and Contemporary Problems. Vol. 53, Summer, p.227-301, 1990. Disponível em: <http://scholarship.law.duke.edu/lcp/vol53/iss3/8/>. Acesso em: 02 jul. 2016.

SCHAFFER, Frederick P. A Guide to Academic Freedom. In: Journal of Collective Bargaining in the Academy. Vol. 0, Iss. 9, april, Article 12, p. 01-53, 2014. Disponível em:

<http://thekeep.eiu.edu/jcba/vol0/iss9/12>. Acesso em: 12 jun.2016.

SCHRECKER, Ellen. No Ivory Tower: McCarthyism and the Universities. Oxford: Oxford University Press, 1986.

SCHRECKER, Ellen. Political Tests for Professors: Academic Freedom during the McCarthy Years. In: The University Loyalty Oath: a $50^{\text {th }}$ Anniversary Retrospective Symposium. History Project. Center for Studies in Higher Education. University of California. October 7, 1999. Disponível em:

<http://www.lib.berkeley.edu/uchistory/archives_exhibits/loyaltyoath/symposium/schrecker.h tml>. Acesso em: 05 jun. 2016.

SEARLE, John R. Academic Freedom. The Campus War: a sympathetic look at the University in agony. 1971. Disponível em: <http://www.ditext.com/searle/campus/6.html>. Acesso em: 03 jul. 2016.

SUPREME COURT OF CANADA. Regina v. Keegstra, 1990. Disponível em: <http://www.canlii.org/en/ca/scc/doc/1990/1990canlii24/1990canlii24.html>. Acesso em: 01 jul. 2016.

TEIXEIRA, Anísio. Educação é um direito. São Paulo: Companhia Editora Nacional, 1968.

TSESIS, Alexander. Dignity and Speech: The Regulatory of Hate Speech in a Democracy. In: Wake Forest Law Review. Vol. 44, p.497-532, 2009. Disponível em:

<http://papers.ssrn.com/sol3/papers.cfm?abstract_id=1402908>. Acesso em: 14 jan.2014.

UNITED STATES SUPREME COURT CENTER. Justia.Com. Disponível em: <http://supreme.justia.com/>. Acesso em: 10 ago.2016.

UNITED STATES SUPREME COURT. Adler v. Board of Educantion of City of New York, 1952.

UNITED STATES SUPREME COURT. Sweezy v. New Hampshire, 1957.

UNITED STATES SUPREME COURT. Keyishian v. Board of Regents, 1967. 
VAN ALSTYNE, William W. The Specific Theory of Academic Freedom and the General Issue of Civil Liberty. In: Academic Freedom and Civil Liberties - The Annals of the American Academy. Faculty Publications. Paper 792, p.140-156, 1972. Disponível em:

<http://scholarship.law.wm.edu/facpubs/792>. Acesso em: 01 jul. 2016.

VAN ALSTYNE, William W. Academic Freedom and the First Amendment in the Supreme Court of the United States: An Unhurried Historical Review. In: Law and Contemporary Problems. Vol. 53, No. 03, Summer, p.79-154, 1990. Disponível em:

<http://scholarship.law.duke.edu/lcp/vol53/iss3/4>. Acesso em: 30 jun. 2016.

YOUN, Monica. The Chilling Effect and the Problem of Private Action. Vanderbilt Law Review. Vol. 66:5, p.1473-1539, 2013. Disponível em:

<https: / / www.vanderbiltlawreview.org/2013/10/the-chilling-effect-and-the-problem-ofprivate-action/>. Acesso em: 04 jun. 2016. 